Matgorzata Pietrasiak

Uniwersytet Łódzki

\title{
Metody i środki realizacji celów polityki ChRL w relacjach $\mathrm{z}$ ASEAN
}

Azja Południowo-Wschodnia zawsze była priorytetowym regionem w strategii chińskiej. Tutaj też są najbardziej widoczne zmiany dotyczące wykorzystywanego arsenału metod i środków potrzebnych do realizacji chińskich interesów, które Jan Rowiński określił jako „odrodzenie wielkości chińskiej nacji” (zhongguo minzu de weidade fuxing) i ,przywrócenie Chinom należnego miejsca w społeczności międzynarodowej jako światowemu mocarstwu"1.

Mimo że w wypowiedziach ekspertów i polityków tego regionu pojawia się obawa związana z hegemonicznym nastawieniem „wzrastających” Chin, kosztem słabszych partnerów, to wśród państw ASEAN istnieje gotowość do przyznania należnej im roli. Okoliczności sprzyjające wzajemnej współpracy to wzrost gospodarczy, nie tylko Chin, ale i całego regionu, zatem we wzajemnym interesie leży jego zabezpieczenie poprzez stabilizację polityczną i gospodarczą. Z inicjatywy obu stron pojawiły się projekty konsolidacyjne, takie jak: East Asia Summit, ACFTA, ASEAN Community 2015 czy Karta ASEAN, które mają służyć wzmocnieniu więzi i stabilizacji sytuacji w regionie. Te nadal zawierają wiele pułapek szkodzących wzajemnym relacjom, takich jak: nierozwiązane kwestie wojskowo-polityczne, wciąż istniejące spory graniczne, zagrożenia transnarodowe, np.: terroryzm, nielegalny przemyt narkotyków, broni, handel ludźmi, korupcja.

Bogusława Drelich-Skulska wymienia trzy scenariusze strategicznych celów Chin:

1. Zmierzają one do uzyskania statusu regionalnego lidera ekonomicznego i domniemanego sponsora.

2. Są zainteresowane ukształtowaniem multilateralnego forum wykluczającego Stany Zjednoczone, tj. East Asian Summit, i przewodzeniem mu.

1 J. Rowiński, Dylematy Chin w końcu I dekady XXI w. (reperkusje kryzysu finansowo-gospodarczego), rękopis. 
3. Ich dążeniem pozostaje osłabienie bilateralnych więzi militarnych państw ASEAN-USA ${ }^{2}$.

Instrumentami dla realizacji tych strategii są przede wszystkim porozumienia dwustronne i wielostronne dotyczące wymiany handlowej i inwestycji kapitałowych. Chiny coraz umiejętniej stosują przy tym cały arsenał środków soft power. Środki, które można wymienić w grupie tzw. twardych hard power, częściej są traktowane jako możliwe, potencjalne, ale realne do realizacji celów polityki chińskiej. Omówienie jednych i drugich na tle sytuacji w regionie jest celem niniejszego artykułu.

\section{Specyfika regionu Azji Południowo-Wschodniej a interesy chińskie}

Punktem wyjścia w rozważaniach dotyczących tego wątku są fundamenty historyczne i cywilizacyjne niemal wszystkich państw regionu. Chińska cywilizacja promieniowała bowiem na sąsiadów. Chińczycy byli lepiej zorganizowani i wykształceni. W tej hierarchii narody niehańskie zajmowały niższą pozycję. Chińczycy oceniali je przez pryzmat własnej kultury i społecznych zachowań.

Cesarskie roszczenia do panowania nad całym światem, dążenie Chin do występowania jako przykład niebiańskiego porządku, mającego własną specyfikę kulturalną, czyniło niemożliwą do urzeczywistnienia zasadę równości w stosunkach z innymi, barbarzyńskimi krajami³. Swoją „opiekę” Chiny uważały za coś pozytywnego, a nawet nobilitującego. Okres po proklamowaniu Chińskiej Republiki Ludowej w żaden sposób nie zmienił tradycyjnego sposobu postrzegania przez Chińczyków roli, jaką powinni odgrywać w regionie. Od 1949 r. ChRL dążyła do utrwalania przyjaznych reżimów na jej peryferiach i maksymalizacji swoich wpływów politycznych. Przyciągnięcie tych państw w obszar własnej orbity wpływów, stworzenie wspólnego bloku antyimperialistycznego i antykolonialnego było celem dyplomacji chińskiej .

Rozłam w bloku państw komunistycznych, eksponowanie przez Chiny własnej wizji ładu międzynarodowego - idei trzech światów i podziału państw na zwalczające się bloki oraz państwa trzeciego świata - sprawił, że również w tym kontekście Azja Południowo-Wschodnia była dobrym polem doświadczalnym dla chińskiej strategii wykreowania się na przywódcę tej grupy. W 1982 r. Deng Xiaoping powiedział na temat chińskiej polityki zagranicznej: „Kto cierpi z powodu

2 B. Drelich-Skulska, Proces integracji Chin z krajami ASEAN. Uwagi wstępne, „Studia Ekonomiczne" 2010, nr 4, s. 392.

3 P. Buckley Ebrey, Historia Chin, Wydawnictwo Muza, Warszawa 2002, s. 55-56.

${ }^{4}$ Leung Yu-Chiu Raymond, The ASEAN Countries in China's Foreign Policy, 1967-76, University of Hong Kong 1983, s. 10. 
hegemonizmu? Czyżby USA i ZSRR? Nie, to właśnie oni zajmują się hegemonizmem i nie oni są jego ofiarami. Europa, Japonia, kraje Oceanii, Kanady i inne rozwinięte kraje także nie są ofiarami. [...] Gdzie toczą się małe wojny? Na obszarze krajów trzeciego świata. Ich źródłem są prowokacje i ingerencja ze strony hegemonizmu mocarstw światowych! [...] Chiny są członkiem trzeciego świata i jako takie powinny wypełniać swój obowiązek. Według słów wielu przyjaciół - Chiny to lider trzeciego świata"s.

Wizerunek Chin, stojących na czele państw rozwijających się w regionie Azji Południowo-Wschodniej, był systematycznie utrwalany, nawet w okresie, gdy Chiny stały się drugą potęgą gospodarczą świata.

Azja Południowo-Wschodnia jest regionem bardzo zróżnicowanym, ale wspomniane wspólne cywilizacyjne fundamenty sprawiają, że w zakresie formułowania celów politycznych, a także ich realizacji można znaleźć wiele podobieństw. Podobnie jak Chiny, wszystkie państwa regionu eksponują wolę zachowania i umocnienia własnej suwerenności, co sprzyja poparciu idei budowy świata wielobiegunowego. Wspólnota celów w tym zakresie wynika z trudnych doświadczeń historycznych. Większość państw regionu, w tym Chiny, dopiero w drugiej połowie XX w. rozpoczęła budowę niezależnego bytu państwowego, stąd - z jednej strony - przywiązanie do idei suwerenności, ale też z drugiej strony - dążenie do dywersyfikacji partnerów czy obawa przed uzależnieniem od mocarstw. Z całą pewnością przywiązywania wagi do dywersyfikowania partnerów nie należy wiązać jedynie z regionem Azji Wschodniej, ponieważ praktyka polityczna wskazuje, że pomimo systematycznego wzrostu wpływów Chin operowanie w regionie takich graczy, jak: USA, Japonia, i w mniejszym, choć zauważalnym stopniu, Rosji i Indii pozwala na rozgrywanie własnych interesów.

Wreszcie wielobiegunowość można rozpatrywać z innego punktu widzenia - zachowania różnorodności. W Azji Wschodniej mamy do czynienia z różnorodnością systemów politycznych, przy pewnych cechach wspólnych. Systemy owe są najrozmaitsze: monarchia absolutna - Brunei; monarchie konstytucyjne: Japonia, Malezja, Tajlandia, Kambodża; republiki: Indonezja, Filipiny, Singapur i Timor Wschodni, trzy państwa socjalistyczne: Chiny, Laos i Wietnam oraz hunta wojskowa - Myanmar. Z kolei idee takie, jak: nadrzędna rola grupy wobec jednostki, rodzina jako podstawa państwa, budowanie ładu na konsensusie społecznym, na zgodzie, a nie na konflikcie, oraz pokojowa rola religii są podstawą tzw. wartości azjatyckich, które lansował premier Malezji Mahathir bin Mohamad ${ }^{6}$.

5 Polityka zagraniczna Chin. Fragmenty rozmowy z Sekretarzem Generalnym ONZ H. de Culiar, [w:] Deng Xiaoping, Chiny na drodze reform w XXI wieku, Wydawnictwo Adam Marszałek, Toruń 2007, s. 151-153.

${ }^{6}$ Mahathir bin Mohamad, Rozważania o wartościach azjatyckich, „Azja-Pacyfik. Społeczeństwo. Polityka. Gospodarka" 1999, t. 2, s. 157-168. 
Opisując znaczenie regionu z punktu widzenia interesów chińskich należy wskazać na jego potencjał gospodarczy. Czynniki, na które w swoim opracowaniu wskazała B. Drelich-Skulska, to: bogactwa naturalne, rynek z $600 \mathrm{mln}$ konsumentów oraz bezpośrednie inwestycje kapitałowe 7 . Jeśli chodzi o bogactwa naturalne, należy wziąć pod uwagę zwłaszcza bogate złoża ropy naftowej i gazu ziemnego. Rezerwy ropy naftowej w Indonezji to 3,7 bln baryłek i 1,2\% wydobycia światowego. W 2009 r. kraj ten produkował 1023000 (liczonej w tysiącach) baryłek ropy naftowej dziennie, co plasowało go na 21. miejscu w świecie. Malezja zajmowała 27. miejsce, z wydobyciem 693700 baryłek dziennie, Tajlandia, z wydobyciem 380000 baryłek dziennie - 33., a Wietnam, z wydobyciem 300600 baryłek dziennie -35 . Z kolei największe zasoby gazu ziemnego w regionie mają: Malezja - 2\% zasobów światowych i Indonezja $-2,7 \%$; wydobycie tych państw to odpowiednio $1,3 \%$ oraz $1,7 \%$ wydobycia światowego ${ }^{8}$. Dla rozpędzonej gospodarki chińskiej są to ważne przesłanki do współpracy z tymi państwami.

Odnosząc się do tradycyjnie regionalnych interesów politycznych Chin, należy wziąc pod uwagę kolejny aspekt, związany ze znaczącymi diasporami chińskimi w wielu państwach regionu. Największą grupę stanowią oni w Malezji-24\% i w Singapurze - 77\% ${ }^{9}$. Również w pozostałych państwach: Indonezji, Tajlandii, Wietnamie mieszkają duże skupiska Huaciao (zamorskich Chińczyków). W sumie w Azji Wschodniej i na Bliskim Wschodzie mieszka blisko 33 mln obywateli pochodzenia chińskiego. Ustawa o obywatelstwie (Nationality Law of the People's Republic of China) zezwala na podwójne obywatelstwo wszystkim, którzy urodzili się za granicą, a rodzice lub jedno z nich są z pochodzenia Chińczykami. Obecnie rozwój gospodarczy Chin zachęca do powrotu lub robienia interesów z „krajem przodków”. W przeszłości Chińczycy ci często byli uważani za konia trojańskiego w regionie, a problemy związane $\mathrm{z}$ ich traktowaniem stanowiły pretekst do konfliktów dwustronnych, jak np. w relacjach chińsko-wietnamskich.

Podsumowując, w chińskiej strategii region Azji Południowo-Wschodniej i ASEAN ważny jest nie tylko w kontekście zachowania tradycyjnych wpływów politycznych, ale też ze względu na rosnące potrzeby koordynowania rozwoju gospodarczego i utrzymania wzrostu gospodarczego, charakterystycznego nie tylko dla Chin, ale i dla pozostałych państw regionu.

7 B. Drelich-Skulska, op. cit., s. 390.

8 Dane na podstawie International Energy Agency Statistics, http://www.iea.org/stats/ [dostęp 15.12.2011].

9 D.E. Weatherbee, International Relations in Southest Asia. The Struggle for Autonomy, Rowman\&Littlefield Publishers, INC 2005, s. 10. 


\section{Kierunki i etapy współpracy Chiny-ASEAN}

W relacjach Chiny-ASEAN, od momentu powstania tej organizacji, wyraźnie rysują się cztery podstawowe etapy ${ }^{10}$ :

1) konfrontacji - od powstania ASEAN do połowy lat 70. XX w.,

2) pojednania - koniec lat 70 . XX w.,

3) współpracy - od początku lat 80 . do połowy lat 90 . XX w.,

4) partnerstwa - po zimnej wojnie.

Okres pierwszy przypada na lata konfliktu indochińskiego, kiedy stowarzyszenie ASEAN przez stronę chińską utożsamiane było z paktem militarnym pozostającym pod wpływem Stanów Zjednoczonych. Członkowie ASEAN byli „lokajami Stanów Zjednoczonych”, a samo Stowarzyszenie Narodów Azji Południowo-Wschodniej określano jako ugrupowanie antychińskie i ,reakcyjna klika" ${ }^{11}$. W czasie wojny indochińskiej niektórzy członkowie ASEAN, np. Tajlandia czy Filipiny, jako sojusznicy Stanów Zjednoczonych, aktywnie angażowali się po amerykańskiej stronie konfliktu. Spośród założycielskiej piątki jedynie Indonezja miała formalnie nawiązane stosunki dyplomatyczne z Chinami, choć zamach stanu z 1965 r. znacznie je oziębił.

Okres drugi rozpoczyna wizyta prezydenta Nixona w 1972 r. w Chinach i podpisanie komunikatu szanghajskiego. Wydarzenie to dało początek normalizacji stosunków ze Stanami Zjednoczonymi i ich sojusznikami. Chiny powoli zaczynały wychodzić z izolacji politycznej. Wrogiem numer jeden został Związek Radziecki, w najlepszym wypadku traktowany na równi ze Stanami Zjednoczonymi. Dodatkowo chińska koncepcja „trzeciego świata”, która nawiązywała do walki z hegemonizmem (amerykańskim i radzieckim), oraz rola w walce z nim sprzyjały poszukiwaniu sojuszników. Azja, poza Japonią, zaliczana była do trzeciego świata i w związku z tym była naturalnym sojusznikiem Chin.

Okres trzeci przypadł na lata 80 . ubiegłego stulecia. Chiny zintensyfikowały wysiłki na rzecz nawiązania stosunków dyplomatycznych z państwami ASEAN, tym bardziej że ich pozycje w wielu kwestiach międzynarodowych stały się zbieżne - zwłaszcza po wkroczeniu wojsk wietnamskich do Kambodży rządzonej przez Czerwonych Khmerów. Zarówno Chiny, jak i ASEAN były przeciwne tej interwencji i obawiały się wzrostu znaczenia politycznego i militarnego „małego hegemona" w regionie, współpracowały więc ze sobą na forum ONZ, dążąc do przyjęcia rezolucji potępiającej interwencję wietnamską.

Ostatni okres rozpoczął się po zimnej wojnie. Kuik Cheng-Chwee (Malezja) wydzielił tu trzy fazy: pierwszą, przypadającą na wczesne lata 90. XX w., nazwał

${ }_{10}$ Han Feng, Envolving Security Environment in Southeast Asia: A Chinese Assessment, [w:] ASEAN-China Relations: Realities and Prospects, eds. Saw Swee-Hock, Sheng Lijun, Chin Kin Wah, ISEAS Publications, Singapore 2005, s. 181.

11 „Peking Review”, 18.08.1967, s. 40. 
pasywnym udziałem, drugą (1996-1999) - aktywnym uczestnictwem, wreszcie współczesną - fazą proaktywnych propozycji ${ }^{12}$.

Wspólne interesy ASEAN i Chin, idące w parze z polityką otwarcia Chin, nakreśliły płaszczyznę porozumienia. Cechą systemu międzynarodowego po zimnej wojnie były też tendencje integracyjne sprzyjające budowaniu wspólnych instytucji. Proces ten w Azji Południowo-Wschodniej ułatwiały dodatkowe okoliczności: zmniejszenie obecności amerykańskiej w regionie, dezintegracja ZSRR i wycofanie się Rosji z aktywnej polityki w regionie, pozytywne procesy w Indochinach oraz wzrost znaczenia gospodarczego i politycznego Chin. Próby nawiązywania dialogu między ASEAN i Chińską Republiką Ludową przypadają na początek lat $90 . \mathrm{XX}$ w. i lata te stanowią cezurę rozpoczynającą kolejny okres w relacjach Stowarzyszenia z Chinami. W tym czasie doszło do odbudowy stosunków między Chinami i Indonezją, rozpoczął się proces normalizacji stosunków z Wietnamem, ponadto Chiny nawiązały stosunki dyplomatyczne z Singapurem ${ }^{13}$. W lipcu $1991 \mathrm{r}$. chiński minister spraw zagranicznych Qian Qichen został zaproszony na ceremonię otwarcia 24. konferencji ministrów spraw zagranicznych ASEAN i od tej pory Chiny uczestniczą w każdym takim spotkaniu. W roku 1994 wzięły udział w konferencji Forum Regionalnego ASEAN (ARF) i w tym samym roku zostały partnerem dialogu konsultatywnego ASEAN ${ }^{14}$. Początkowo sceptyczne, jeśli chodzi o kierunki działalności ARF, obawiając się zachodnich, a głównie amerykańskich wpływów na organizację, Chiny w lipcu 1996 r. stały się 9. pełnoprawnym partnerem dialogu zarówno ASEAN, jak i ARF, razem z innymi państwami: Indiami, Australia, Kanadą, Japonią, Nową Zelandią, Koreą Południową, USA i UE. Cele ASEAN i ChRL zbiegły się. ASEAN dążyło do gospodarczego związania Chin oraz włączenia ich do dialogu na temat bezpieczeństwa w regionie.

Na szczycie, który odbył się Malezji w lipcu 1997 r., minister spraw zagranicznych ChRL Qian Qichen wygłosił ważne przemówienie, w którym nakreślił strategię chińską wobec regionu. Ogólnie można wskazać na bardzo przyjacielski i oparty na konsensusie wydźwięk tej strategii.

Pod koniec 1997 r., oprócz utworzonego w lutym tego roku Wspólnego Komitetu ds. Współpracy Chiny-ASEAN (ASEAN-China Joint Cooperation Committee - ACJCC), istniało już kilka równoległych form dialogu między ASEAN i Chinami: polityczne konsultacje na poziomie wyższych urzędników (Senior Officials Meeting, SOM), Wspólny Komitet ds. Współpracy Naukowej i Tech-

12 Kuik Cheng-Chwee, Multilateralizm in China's ASEAN Policy: Its Evolution, Characteristics, and Aspiration, „Contemporary Southeast Asia” [Institute of Southeast Asian Studies] 2005, vol. 27.

13 Jing-dong Yuan, China-ASEAN Relations: Perspectives, Prospects and Implications for the U.S. Interest, October 2006, http://www.strategicstudiesinstitute.army.mil/pdffiles/pub735.pdf [dostęp 15.05.2011].

14 Ibidem. 
nologicznej, Komitet ds. Gospodarczych i Handlowych oraz Komitet w Pekinie, który tworzyli ambasadorowie państw ASEAN. Chiny uczestniczyły w pracach ARF oraz Radzie Biznesu ASEAN-Chiny ${ }^{15}$. W ramach dialogu multilateralnego, wzmacniając również kontakty bilateralne, Pekin realizuje swoje cele polityczne i gospodarcze, polegające na stworzeniu sprzyjających warunków dla dalszego stabilnego rozwoju.

Obie strony stawiają na bezpośrednie kontakty. Warto podać tu przykład, że jedynie w 2010 r. miało miejsce aż 70 wizyt na różnym szczeblu ${ }^{16}$. W $2010 \mathrm{r}$. zakończono realizację planu działań nakreślonych we Wspólnej deklaracji partnerstwa strategicznego na lata 2005-2010 Chiny-ASEAN (Joint Declaration on China-ASEAN Strategic Partnership for Peace and Prosperity) oraz sformułowano kolejny plan działań, na lata 2011-2015.

\section{Narzędzia gospodarcze}

Przegląd metod gospodarczych realizacji celów polityki chińskiej wobec regionu Azji Południowo-Wschodniej należy, bez wątpienia, rozpocząć od roku 1997. Wówczas azjatycki kryzys finansowy pokazał, że Chiny mogą i chcą odgrywać konstruktywną rolę w regionie. Dla wielu państw „,agresywna” obecność Chin na rynkach ASEAN budziła niepokój w kontekście ich historycznych ambicji w stosunku do regionu oraz wzrostu wpływów politycznych czy militarnych ${ }^{17}$. Komentatorzy przedstawiali tę sytuację w kategoriach „chińskiego zagrożenia” dla gospodarek państw ASEAN, których struktura eksportu była podobna.

Niemniej jednak kryzys zmusił państwa do większej troski o własną stabilizację, bez względu na potencjalne zagrożenia ze strony odbudowujących swoją potęgę Chin. Formą instytucjonalizacji współpracy liderów regionu z ASEAN było ASEAN+3 (APT) ${ }^{18}$. Pierwszy raz APT spotkało się w Kuala Lumpur w grudniu 1997 r. Japonia wyszła z inicjatywą powołania Azjatyckiego Funduszu Walutowego (Asian Monetary Fund). Chiny, początkowo przeciwne jego utworzeniu, z czasem patrzyły na inicjatywę przychylniej, aktywnie włączając się w budowanie struktury finansowej w regionie, dzięki czemu wzmocniły swoją pozycję, a dodatkowo zbudowały lepszy aparat, by chronić region przed kolejnymi kryzysami ${ }^{19}$.

15 Saw Swee-Hock, Sheng Lijun, Chin Kin Wah, An Overview of ASEAN-China Realtions, [w:] ASEAN-China Relations..., s. 2.

$16 \mathrm{http}: / /$ news.xinhuanet.com/english2010/china/2011-11/15/c_131248640_2.htm [dostęp 20.07.2012].

17 Han Feng, op. cit., s. 183.

18 S. Narine, The Idea of an „Asian Monetary Fund”: The Problems of Financial Institutionalism in the Asia-Pacific, „Asian Perpective” 2003, vol. 27, no. 2, s. 82-83.

19 P. Lipscy, Japan's Asian Monetary Fund Proposal, http://www.stanford.edu/group/sjeaa/ journal3/japan3.pdf [dostęp 20.07.2012]. 
Kryzys pokazał, że ani APEC, ani Międzynarodowy Fundusz Walutowy nie są w stanie pomóc regionowi przezwyciężyć kryzys. Chiny udzieliły pożyczki Tajlandii w wysokości jednego mld USD i odmówiły dewaluacji juana w ślad za dewaluacją wielu walut wschodnioazjatyckich, co pomogło poprawić ich wizerunek $^{20}$.

W maju 2000 r. APT podjęło ważne zobowiązanie znane pod nazwą Chiang Mai Initiative: ministrowie finansów APT zgodzili się ustanowić dwustronne porozumienia swap między bankami azjatyckimi, aby wzmocnić regionalną stabilność finansową. W 2009 r. istniało już 16 dwustronnych porozumień w ramach grupy ASEAN+3, a państwa zobowiązały się do wydzielenia rezerw walutowych, które w marcu 2010 r. wyniosły 120 mld USD i miały wzrosnąć do 240 mld USD w roku $2012^{21}$.

W 2001 r., na szczycie państw ASEAN w Bandar Seri Begawan, premier Zhu Rongji przedstawił pięciopunktowe stanowisko Chin na temat promocji współpracy w Azji Wschodniej, w której pozytywną rolę odgrywałyby Chiny. Wymienił tu: konieczność zdefiniowania celów rozwojowych, ram współpracy handlu regionalnego i wzajemnie korzystnych inwestycji w dziedzinach finansowych, nauki i technologii, informacji, ochrony środowiska, rozwój i lepszą koordynację współpracy w ramach ASEAN+3 oraz ASEAN+1 - różnorodne i wzajemnie uzupełniające się formy, kontynuowanie współpracy w sektorze finansowym, wymianę między różnymi grupami społecznymi oraz dialog i współpracę w sferze bezpieczeństwa ${ }^{22}$.

Pomimo istniejących wątpliwości, bez wątpienia początek XXI w. to większe zbliżenie tych dwóch podmiotów międzynarodowych. Rozpoczął się bum kredytowy, Chiny z biorcy pomocy rozwojowej stały się dawcą, udzielały pożyczek państwom ASEAN. Konkurencja Chin z Japonią o wpływy geopolityczne wymusiła na obu państwach własną politykę inwestycyjną. Wśród wielu określeń tej polityki analitycy używają pojęcia charm offensive (czarująca ofensywa) ${ }^{23}$, która ma świadczyć o nowych metodach realizacji celów chińskiej polityki zagranicznej. W słowniku przywódców chińskich na stałe zagościły słowa „wzajemnie korzystna współpraca" (win-win cooperation) ${ }^{24}$.

20 E. Kanajew, ASEAN-KNR: Nowaja paradigma otnoszenii $j w$ sfierie biezopasnosti, [w:] Problemy nacyonalnoj biezopasnosti wo wnieszniej politikie Kitaja, red. G. Czufrin, IMEMO RAN, Moskwa 2005, s. 115.

21 http://www.thenews.com.pk/Todays-News-3-98519-Briefs [dostęp 15.07.2012].

22 http://www.fmprc.gov.cn/eng/gjhdq/dqzzywt/2633/2634/2636/t15559.htm [dostęp 5.11.2011].

23 I. Storey, The United States and ASEAN-China Relations: All Quiet on the Southeast Asian Front, October 2007, http://www.StrategicStudiesInstitute.army.mil [dostęp 15.05.2011].

24 J. Kurlantzick, Charm Offensive. How China's Soft Power Is Transforming the World, A New Republic Book, New York 2007, s. 43. 
Analizując kolejne ważne etapy wzajemnych relacji gospodarczych między Chinami i ASEAN należy przywołać postanowienie liderów dziesięciu państw ASEAN i Chin z listopada 2000 r., którzy zgodzili się wzmocnić współpracę poprzez tworzenie strefy wolnego handlu (China-ASEAN Free Trade Area - CAFTA). W 2002 r. podpisano porozumienie o liberalizacji o $99 \%$ handlu ze starymi państwami ASEAN do 2010 r. i do 2015 r. z pozostałymi. Dla Chin najważniejszym celem tego przedsięwzięcia była pełna integracja własnej gospodarki z globalną w charakterze centrum światowego przemysłu. Chińczykom chodziło o pełniejsze otwarcie rynków azjatyckich, które do tej pory absorbowały jedynie 8\% chińskiego eksportu. Ekspert chiński Hu Angang obrazowo nazwał preferowany przez Chiny model handlu z państwami ASEAN modelem półotwartym, tzn. „otwartym na wolny eksport, ale protekcjonistycznym, jeśli chodzi o import" ${ }^{25}$. Z kolei celem państw ASEAN było zwiększenie ich konkurencyjności i współpraca gospodarcza z szybko rozwijającymi się Chinami, w tym przyciąganie chińskich inwestycji. CAFTA jest jednym z ważniejszych zagadnień dotyczących bezpieczeństwa między stronami, ponieważ w strategii państw ASEAN rozwój powiązań gospodarczych sprzyja umacnianiu bezpieczeństwa i stabilności. Przywódcy państw ASEAN dementowali oceny mówiące o całkowitej nierówności we wzajemnych relacjach. Minister Singapuru George Yeo, przemawiając w 2002 r., powiedział: „Nie chcemy pozostawać w relacjach poddańczych w stosunku do Chin"26.

Ciekawą inicjatywą w ramach współpracy ASEAN z Chinami jest powołanie Boao Forum dla Azji, które działa od 2001 r. To najbardziej prestiżowa organizacja non profit, powołana w celu promowania regionalnej integracji gospodarczej i realizacji celów rozwojowych ${ }^{27}$.

W 2006 r., w 15. rocznicę nawiązania współpracy, Chiny i ASEAN nie szczędziły wzajemnych pochwał, aby udowodnić i pokazać, jak bardzo intensywne są związki między nimi. Premier Wen Jiabao stwierdził, że od 1991 r. widać, jak strony systematycznie dążą do budowy wzajemnego zaufania, eliminowania przeszkód oraz budowy dialogu i dobrej atmosfery. W rezultacie stosunki ChinyASEAN znalazły się na najwyższym etapie historycznego rozwoju ${ }^{28}$. W $2008 \mathrm{r}$. Chiny akredytowały swojego pierwszego ambasadora przy ASEAN panią Xue Hanqin ${ }^{29}$. Przemawiając w instytucie ASEAN w Singapurze w roku 2009,

${ }_{25} \mathrm{http}$ //www.tni.org/article/china-asean-free-trade-area-propaganda-and-reality [dostęp 5.08.2012].

26 I. Storey, op. cit., s. 10.

$27 \mathrm{http} / / /$ english.boaoforum.org/gyltbjjsen/index.jhtml [dostęp 5.08.2012].

28 Wen's Speech at China-ASEAN Summit, http://www.chinadaily.com.cn/china/2006-10/30/ content_720281_2.htm [dostęp 5.11.2011].

${ }_{29}$ China Appoints Female Diplomat as First ASEAN Ambasador, http://www.gov.cn/english/2008-12/30/content_1192260.htm [dostęp 5.11.2011]. 
wymieniła ona cztery wartości, które powinny być spełnione, aby następował stały rozwój wzajemnych relacji: oparcie ich na wzajemnym zrozumieniu i zaufaniu, wyłonienie przywódców i instytucji kreujących i stymulujących rozwój relacji, zwrócenie szczególnej uwagi na wzajemny handel i gospodarkę, które są siłą napędową kontaktów, wymiana kulturalna i kontakty międzyludzkie, które stanowią „społeczną fundację na rzecz współpracy Chiny-ASEAN"30.

W 2009 r. z inicjatywy premiera Wen Jiabao powstał China-ASEAN Investment Cooperation Fund (CAF), który skupia się na inwestycjach w infrastrukturę, energetykę oraz zasoby naturalne.

W dniu 1 stycznia 2010 r. miało miejsce otwarcie strefy wolnego handlu CAFTA. Dla jej zbudowania potrzeba było 8 lat, ale obecnie obejmuje ona 11 państw, gdzie mieszka 1,9 mld ludzi. Cło na towary między tymi państwami zmniejszyło się średnio od $9,8 \%$ do $0,1 \%$. Wewnątrz strefy z powodzeniem rozwija się projekt subregionalny rzeki Mekong, z udziałem Chin, Wietnamu, Laosu, Kambodży i Myanmaru. Według ekspertów wolny handel obejmie ponad 7000 różnych towarów i będzie stanowił ok. $90 \%$ całego handlu między Chinami i ASEAN. Projekt obejmie również sferę usług i umów inwestycyjnych ${ }^{31}$.

Jakie są efekty CAFTA wyrażone w liczbach? Jeśli chodzi o wielkość handlu, w 2010 r. wzajemna wymiana przewyższyła 280 mld USD. Minister spraw zagranicznych Yang Jiechi oznajmił, że wymiana handlowa w ramach chińsko-aseańskiej strefy wolnego handlu (CAFTA) wzrosła do ok. 360 mld USD w $2011 \mathrm{r}^{32}$ Tabela 5.2 pokazuje obroty handlowe Chin z państwami ASEAN do 2008 r.

Tabela 5.1.

Obroty handlowe państw ASEAN z Chinami w latach 2004-2008 (wartość w milionach USD)

\begin{tabular}{|l|r|r|r|r|r|}
\hline \multicolumn{1}{|c|}{ Państwo } & \multicolumn{1}{c|}{2004} & 2005 & 2006 & 2007 & \multicolumn{1}{c|}{2008} \\
\hline \multicolumn{1}{|c|}{1} & \multicolumn{1}{c|}{2} & 3 & 4 & 5 & \multicolumn{1}{c|}{6} \\
\hline Brunei Darussalam & 243 & 234 & 174 & 201 & 0 \\
Kambodża & 12 & 15 & 13 & 11 & 13 \\
Indonezja & 4605 & 6662 & 8344 & 8897 & 11637 \\
Laos & 1 & 4 & 1 & 35 & 15 \\
Malezja & 8634 & 9465 & 11391 & 15443 & 18422 \\
Myanmar & 75 & 119 & 133 & 475 & 499 \\
\hline
\end{tabular}

${ }_{30}$ Xue Hanqin, China-ASEAN Cooperation. A Model of Good-Neighbourliness and Friendly Cooperation http://www.iseas.edu.sg/aseanstudiescentre/Speech-Xue-Hanqin-19-9-09.pdf [dostęp 5.11.2011].

31 S. Luzanin, Wnieszniaja politika Kitaja do 2020 g. Prognosticzeskij diskurs, http://www. mgimo.ru/news/experts/document213521.phtml [dostęp 18.08.2012].

32 http://www.fmprc.gov.cn/eng/wjb/zygy/gyhd/t950203.htm [dostęp 20.08.2012]. 


\begin{tabular}{|l|r|r|r|r|r|}
\hline \multicolumn{1}{|c|}{1} & \multicolumn{1}{|c|}{2} & \multicolumn{1}{c|}{3} & \multicolumn{1}{c|}{5} & \multicolumn{1}{c|}{5} \\
\hline Filipiny & 2653 & 4077 & 4628 & 5750 & 5467 \\
Singapur & 15321 & 19770 & 26472 & 28925 & 29082 \\
Tajlandia & 7098 & 9083 & 10840 & 14873 & 15931 \\
Wietnam & 2711 & 2828 & 3015 & 3336 & 4491 \\
\hline ASEAN Export & $\mathbf{4 1 3 5 2}$ & $\mathbf{5 2} \mathbf{2 5 8}$ & $\mathbf{6 5 0 1 0}$ & $\mathbf{7 7 9 4 5}$ & $\mathbf{8 5 5 5 8}$ \\
\hline Brunei Darussalam & 87 & 94 & 120 & 157 & 171 \\
Kambodża & 337 & 430 & 516 & 653 & 933 \\
Indonezja & 4101 & 5843 & 6637 & 8616 & 15247 \\
Laos & 89 & 185 & 23 & 43 & 131 \\
Malezja & 11353 & 14361 & 15543 & 18897 & 18646 \\
Myanmar & 351 & 286 & 397 & 564 & 671 \\
Filipiny & 2659 & 2973 & 3647 & 4001 & 4250 \\
Singapur & 16137 & 20527 & 27185 & 31908 & 31583 \\
Tajlandia & 8183 & 11116 & 13578 & 16184 & 19936 \\
Wietnam & 4416 & 5322 & 7306 & 12148 & 15545 \\
\hline ASEAN Import & $\mathbf{4 7 \mathbf { 7 1 4 }}$ & $\mathbf{6 1 \mathbf { 1 3 6 }}$ & $\mathbf{7 4 9 5 1}$ & $\mathbf{9 3} \mathbf{1 7 3}$ & $\mathbf{1 0 7} \mathbf{1 1 4}$ \\
\hline
\end{tabular}

Źródło: ASEAN Trade Statistics Database, http://www.aseansec.org/23752.htm.

Wzrost obrotów handlowych między Chinami i ASEAN przekłada się na zmianę geograficznej struktury obrotów Chin z najważniejszymi partnerami, co obrazuje tabela 5.3.

Tabela 5.2.

\section{Zmiany geograficznej struktury obrotów Chin z najważniejszymi partnerami}

\begin{tabular}{|l|r|r|r|r|r|r|r|r|}
\hline \multirow{2}{*}{ Kraj/Region } & \multicolumn{4}{|c|}{ Eksport Chin } & \multicolumn{4}{c|}{ Import Chin } \\
\cline { 2 - 10 } & 1990 & 2000 & 2007 & 2010 & 1990 & 2000 & 2007 & 2010 \\
\hline Stany Zjednoczone & 8,5 & 20,9 & 19,5 & 18,3 & 12,2 & 9,9 & 7,5 & 8,0 \\
\hline Japonia & 14,7 & 16,7 & 8,3 & 7,8 & 14,2 & 18,4 & 14,1 & 13,8 \\
\hline ASEAN & $\mathbf{4 , 7}$ & $\mathbf{5 , 2}$ & $\mathbf{1 2 , 4}$ & $\mathbf{8 , 9}$ & $\mathbf{4 , 4}$ & $\mathbf{3 , 5}$ & $\mathbf{9 , 1}$ & $\mathbf{1 2 , 1}$ \\
\hline Unia Europejska & 10,0 & 27,7 & 20,5 & $20,1^{*}$ & 17,0 & 10,7 & 13,0 & 13,2 \\
\hline Rosja & b.d. & 0,9 & 2,3 & 1,9 & 0,0 & 2,6 & 2,0 & 2,0 \\
\hline
\end{tabular}

Uwagi: *UE - 27

Źródło: Opracowanie własne na podstawie: B. Drelich-Skulska, op. cit. oraz China Main Economic Indicators, http://trade.ec.europa.eu/doclib/html/113366.htm. 
Integracja z ASEAN spowodowała, że Chiny stały się ostatnim ogniwem produkcyjnym, wykorzystując komponenty powstałe w państwach ASEAN. Jeżeli po kryzysie $1997 \mathrm{r}$. handel wewnątrz ASEAN rósł powoli, to handel z Chinami wzrósł znacząco $^{33}$. Był on zdominowany przez części i komponenty, produkcję elektroniki i przemysł samochodowy. Natomiast handel wyrobami tekstylnymi, które dla wartości PKB państw ASEAN są najważniejsze, wyraźnie uległ zmniejszeniu.

Większa integracja z Chinami nie zredukowała zależności eksportu państw ASEAN z kierunku państw OECD (Organizacja Wspólpracy Gospodarczej i Rozwoju). W dodatku, ten olbrzymi eksport najczęściej idzie za pośrednictwem Chin, a nie bezpośrednio z OECD. Rezultatem tego zjawiska jest cykliczna fluktuacja zapotrzebowania z tych państw. Gospodarcze więzi ASEAN z Chinami stały się nierozerwalne, a kraje ASEAN częściej są producentami i kooperantami niż ich konkurentami. Integracja produkcji regionalnej wskazuje na wzrost synchronizacji cyklów biznesowych wewnątrz ASEAN oraz między ASEAN i Chinami. Można jednak mówić o pewnym niekorzystnym zjawisku dotyczącym wzajemnego handlu - istniejącym i pogłębiającym się podobieństwie struktury eksportu tych państw, o czym wspomina w swojej analizie B. Drelich-Skulska ${ }^{34}$.

Podsumowując: ASEAN dla Chin to trzeci partner regionalny. W $2010 \mathrm{r}$. obroty z ASEAN stanowiły 10,3\% ogólnej ich wartości. Na pierwszym miejscu jest Unia Europejska - 16,7\%, na drugim państwa NAFTA - 15,8\%. W czołówce są również państwa BRICS - 6,4\% i Ameryka Łacińska - 6,2\%35.

Efektem procesów integracyjnych w ramach CAFTA jest wzrost chińskich bezpośrednich inwestycji zagranicznych (Tabela 5.3). Na wysokim poziomie utrzymują się również inwestycje ASEAN (Tabela 5.4).

Tabela 5.3.

Chińskie inwestycje zagraniczne (BIZ) w państwach ASEAN w latach 2003-2008 (wartość w mln USD)

\begin{tabular}{|l|c|c|c|c|c|c|}
\hline \multicolumn{1}{|c|}{ Państwo } & 2003 & 2004 & 2005 & 2006 & 2007 & 2008 \\
\hline \multicolumn{1}{|c}{1} & 2 & 3 & 4 & 5 & 6 & 7 \\
\hline Świat & $\mathbf{3 3 2 2 2 , 2 2}$ & $\mathbf{4 4 7 7 7 , 2 6}$ & $\mathbf{5 7 2 0 5 , 6 2}$ & $\mathbf{7 5 0 2 5 , 5 5}$ & $\mathbf{1 1 7} \mathbf{9 1 0 , 5 0}$ & $\mathbf{1 8 3} \mathbf{9 7 0 , 7 1}$ \\
\hline Singapur & 164,83 & 233,09 & 325,48 & 468,01 & 1443,93 & 3334,87 \\
Indonezja & 54,26 & 121,75 & 140,93 & 225,51 & 679,48 & 543,33 \\
Wietnam & 28,73 & 160,32 & 229,18 & 253,63 & 396,99 & 521,73 \\
Myanmar & 10,22 & 20,18 & 23,59 & 163,12 & 261,77 & 499,71 \\
\hline
\end{tabular}

33 Southeast Asian Economic Outlook 2010, OECD Publishing pdf [dostęp 18.08.2012], s. 25.

34 B. Drelich-Skulska, op. cit., s. 402.

${ }_{35}$ China Main Economic Indicators, http://rade.ec.europa.eu/doclib/html/113366.htm [dostęp 25.07.2012]. 


\begin{tabular}{|l|r|r|r|r|r|r|}
\hline \multicolumn{1}{|c|}{1} & \multicolumn{1}{c|}{2} & \multicolumn{1}{c|}{3} & \multicolumn{1}{c|}{4} & \multicolumn{1}{c|}{5} & \multicolumn{1}{c|}{6} & \multicolumn{1}{c|}{7} \\
\hline Tajlandia & 150,77 & 181,88 & 219,18 & 232,67 & 378,62 & 437,16 \\
Kambodża & 59,49 & 89,89 & 76,84 & 103,66 & 168,11 & 390,66 \\
Malezja & 100,66 & 123,24 & 186,83 & 196,96 & 274,63 & 361,20 \\
Laos & 9,11 & 15,42 & 32,87 & 96,07 & 302,22 & 305,19 \\
Filipiny & 8,75 & 9,80 & 19,35 & 21,85 & 43,04 & 86,73 \\
Brunei & 0,13 & 0,13 & 1,90 & 1,90 & 4,38 & 6,51 \\
\hline ASEAN & 586,95 & 955,70 & 1256,15 & 1763,38 & 3953,17 & 6486,99 \\
\hline ASEAN\% & \multirow{2}{*}{$1,77 \%$} & $2,13 \%$ & $2,20 \%$ & $2,35 \%$ & $3,35 \%$ & $3,53 \%$ \\
z Świat & & & & & \\
\hline
\end{tabular}

Źródło: J. Kubny, H. Voss, China's FDI in ASEAN: Trends and Impact on Host Countries, http://gdex.dk/ofdi10/Kubny\%20Voss_Chinas\%20FDI\%20in\%20ASEAN.pdf.

Tabela 5.4.

\section{Bezpośrednie Inwestycje Zagraniczne ASEAN w Chinach w mln USD i w procentach w latach 1995-2008}

\begin{tabular}{|l|c|c|c|c|c|c|c|c|c|c|c|}
\hline Rok & BIZ & $\begin{array}{c}\text { Indo- } \\
\text { nezja }\end{array}$ & $\begin{array}{c}\text { Male- } \\
\text { zja }\end{array}$ & $\begin{array}{c}\text { Filipi- } \\
\text { ny }\end{array}$ & $\begin{array}{c}\text { Singa- } \\
\text { pur }\end{array}$ & $\begin{array}{c}\text { Taj- } \\
\text { landia }\end{array}$ & $\begin{array}{c}\text { Wiet- } \\
\text { nam }\end{array}$ & LCM & $\begin{array}{c}\text { Bru- } \\
\text { nei }\end{array}$ & $\begin{array}{c}\text { Ogó- } \\
\text { łem }\end{array}$ & $\%$ \\
\hline 1995 & 48,133 & 112 & 259 & 106 & 1,861 & 288 & 28 & 0 & 0 & 2,654 & 5,5 \\
\hline 1998 & 45,463 & 69 & 340 & 179 & 3,404 & 205 & 14 & 9 & 2 & 4,223 & 9,3 \\
\hline 2002 & 52,743 & 122 & 368 & 186 & 2,337 & 188 & 3 & 36 & 17 & 3,256 & 6,2 \\
\hline 2005 & 60,325 & 87 & 361 & 189 & 2,204 & 96 & 1 & 7 & 160 & 3,105 & 5,1 \\
\hline 2008 & 92,395 & 167 & 247 & 127 & 4,435 & 129 & 2 & 13 & 340 & 5,461 & 5,9 \\
\hline
\end{tabular}

Uwaga: LCM - Laos, Kambodża i Mynamar

Źródło: Sara Y. Tong, Catherine Chong Siew Keng, China-ASEAN Free Trade Area in 2010, www.eai.nus.edu.sg/BB519.pdf.

Według ostatnich danych wartość inwestycji chińskich w sektorze niefinansowym w państwach ASEAN tylko w styczniu-październiku 2011 r. wyniosła 2 mld 336 mln USD. Singapur, Myanmar i Kambodża zajęły trzy pierwsze miejsca, jeśli chodzi o chińskie inwestycje. Ogólnie w ciągu ostatnich trzech lat wielkość chińskich inwestycji w państwach ASEAN osiągnęła 12 mld 426 mln USD. Według przyjętych zasad chińskie przedsiębiorstwa mogą inwestować kapitał w dowolnym państwie ASEAN, a następnie wejść na rynek z wyprodukowanymi towarami w pozostałych dziewięciu państwach członkowskich. Co więcej, mogą wejść na wolny rynek tych wszystkich państw, które mają podpisane porozumienie o wolnym handlu z ASEAN, np. Japonii czy Korei Południowej ${ }^{36}$.

36 S. Luzanin, Kitajskij faktor w ATES: ograniczitiel ili stimulator?, http://www.mgimo.ru/ news/experts/document223349.phtml [dostęp 20.08.2012]. 
Strategia ASEAN+Chiny polega nie tylko na inwestycjach kapitałowych, ale jest też związana z ich obsługą. Pekin umiejętnie wykorzystuje zainteresowanie Tajlandii, Kambodży, Laosu, Wietnamu i Malezji budową agroinfrastruktury.

Pamiętać należy przy tym, że Chiny i państwa ASEAN nadal są konkurentami, jeśli chodzi o przyciąganie kapitału w podobnych dziedzinach przemysłu. W roku 2009 napływ FDI do wszystkich państw ASEAN wyniósł 37 mld USD, natomiast do Chin - 95 mld USD. Ponad 80\% FDI do ASEAN to kapitał spoza regionu. W 2009 r. FDI do ASEAN spadł o ok. 23\%, a do Chin - o ok. 12,3\%.

Jak pisze B. Drelich-Skulska: „Rząd chiński wspiera inwestycje zagraniczne w czterech obszarach:

1. Zabezpieczenie dostaw surowców naturalnych, niezbędnych do utrzymania wewnętrznego wzrostu ekonomicznego.

2. Tworzenie filii chińskich przedsiębiorstw produkcyjnych oraz realizacja projektów infrastrukturalnych, w których wykorzystywane są technologia, produkcja, sprzęt i siła robocza eksportowane z Chin.

3. Zaangażowanie chińskich przedsiębiorstw w projekty badawczo-rozwojowe, które wymagają zaawansowanych technologii, wiedzy menedżerskiej oraz profesjonalnych umiejętności.

4. Fuzje i przejęcia dokonywane przez przedsiębiorstwa z Chin, co umożliwia zwiększenie konkurencyjności rodzimych podmiotów i wzrost ich udziału w globalnym runku"37.

Chiny nastawione są na wzrost swoich inwestycji zagranicznych z różnych przyczyn. Po pierwsze, rośnie liczba liczących się globalnych przedsiębiorstw chińskich. W 2000 r. pięć chińskich przedsiębiorstw transnarodowych znalazło się na liście UNCTAD największych przedsiębiorstw transnarodowych (TNC). Na liście Fortuna Global z 2011 r. było 61 chińskich TNC, rok wcześniej - 46, a w $2005-20^{38}$. Po drugie, chińskie kompanie inwestują, aby polepszyć warunki produkcji. Budowanie wzrostu poza granicami związane jest z kreowaniem dodatkowego zapotrzebowania dla podmiotów krajowych. Po trzecie, chińskie przedsiębiorstwa państwowe są reformowane zgodnie z zaleceniem WTO, co pomaga im się przekształcać. Po czwarte Chiny, tak jak wcześniej Japonia, angażują się, aby zbudować przyjazne środowisko dostarczania strategicznych zasobów naturalnych dla rozwoju ekonomicznego

Podsumowując: Chiny dobrze wykorzystują multilateralne formy współpracy gospodarczej. Przynoszą one korzyści również państwom ASEAN, ponieważ mają one preferencyjne warunki dostępu na rynek chiński i korzystają z kapitału inwestycyjnego. Z kolei Pekin liczy na to, że te krótkoterminowe korzyści przyniosą mu profity w perspektywie długoterminowych celów politycznych i gospodarczych.

37 B. Drelich-Skulska, op. cit., s. 405.

$38 \mathrm{http}: / /$ money.cnn.com/magazines/fortune/global500/2010/countries/Australia.html.

http://money.cnn.com/magazines/fortune/global500/2011/countries/Australia.html; http://money.cnn.com/magazines/fortune/global500/2006/countries/C.html [dostęp 20.08.2012]. 


\section{Chiny i budowa bezpieczeństwa w regionie Azji Południowo-Wschodniej}

Problem bezpieczeństwa w regionie Azji Południowo-Wschodniej jest traktowany szerzej i nie odnosi się jedynie do sektora militarnego, ale również politycznego, społecznego, ekonomicznego czy środowiskowego.

W licznych deklaracjach i oficjalnych wypowiedziach Azja Południowo-Wschodnia opisywana jest jako pluralistyczna wspólnota bezpieczeństwa, rozwiązująca problemy w ,stylu ASEAN" (ASEAN way), czyli na drodze konsensusu i wspólnych wartości. Na tej podstawie budowane jest sprzyjające środowisko dla stabilnego wzrostu gospodarczego. Wzrost gospodarczy ma służyć nie tylko stabilizacji wewnętrznej, ale i przyczyniać się do eliminowania zagrożeń, konfliktów i rebelii. Chiny są zainteresowane wsparciem takich celów, deklarują przywiązanie do podobnych wartości i wykorzystują w tym celu trzy podstawowe instytucje: ARF, ASEAN+3 oraz EAS ${ }^{39}$. Długoterminowe cele polityki chińskiej są związane $\mathrm{z}$ tworzeniem forum multilateralnych, np. EAS, jak również osłabieniem dwustronnych więzi militarnych niektórych państw ASEAN z USA ${ }^{40}$. Rosyjski ekspert ds. Chin Sergiej Luzianin przytacza wypowiedź pracownika Ministerstwa Handlu ChRL, który ostrzega przed zbliżeniem z USA: „Chociaż niektóre państwa mają spory terytorialne z Chinami i niektóre z nich może i liczą na siłę militarną Stanów Zjednoczonych, to powinny rozumieć, że jeśli dojdzie do konfrontacji między Chinami i USA, będą musiały zapłacić za nią wysoką cenę"41.

W innym artykule ten sam ekspert zwraca uwagę na to, że w Azji Wschodniej nadal funkcjonuje przestarzały system bezpieczeństwa, powstały jeszcze w okresie zimnej wojny i polegający na dwustronnych porozumieniach, które służyły interesom USA. Chiny nie mają podobnego systemu bezpieczeństwa, stąd pojawiają się różne idee, w tym i takie, aby średnioterminowym wojskowym celem strategicznym stało się przedstawienie gwarancji bezpieczeństwa sąsiednim państwom ${ }^{42}$.

Zatem realizacja celów chińskich w zakresie budowy bezpieczeństwa militarnego musi uwzględniać zarówno dorobek ASEAN w tym zakresie, czynnik amerykański $\mathrm{w}$ istniejącym systemie, jak i nierozwiązane konflikty: koreański i spory terytorialne w regionie. Najważniejszą inicjatywą, dzięki której budowany jest dialog na temat bezpieczeństwa regionalnego, jest Forum Regionalne ASEAN (ASEAN Regional Forum). Po raz pierwszy konferencja ARF odbyła się w 1993 r.

39 J. Dosch, Managing Security in ASEAN-China Relations: Liberal Peace in Hegemonistic Security, „Asian Perspective” 2007, vol. 31, no. 1, s. 212.

40 I. Storey, op. cit.

${ }^{41}$ S. Luzanin, Kitajskij faktor $w$ ATES...

42 S. Luzanin, M. Mamonow, Kitaj w głobalnych i riegionalnych izmierienijach. Riesursy i marszruty ,,wozwyszenija”, [w:] Kitaj w mirowoj i riegionalnoj politikie. Istorija i sowriemiennost', wyp. XVI, Moskwa 2011, s. 18. 
w Singapurze, a ideą przewodnią rozmów było utworzenie systemu zinstytucjonalizowanego, który by sprzyjał dyplomacji prewencyjnej, przeciwdziałałby konfliktom, zapewniał budowę środków wzajemnego zaufania. Wpływ na podjęcie tej decyzji miało zakończenie zimnej wojny i konieczność wypracowania nowych form współpracy i bezpieczeństwa międzynarodowego.

$\mathrm{Na}$ drugiej konferencji na szczeblu ministerialnym w 1995 r. opracowano trzyfazowy proces budowy bezpieczeństwa poprzez promocję i budowę zaufania, rozwój dyplomacji prewencyjnej i wreszcie proces zapobiegania konfliktom ${ }^{43}$. Hasłem widniejącym na stronie internetowej ARF (http://aseanregionalforum. asean.org/) jest promowanie pokoju i bezpieczeństwa przez dialog i współpracę w regionie Azji i Pacyfiku.

Członkami ARF jest obecnie 27 państw, oprócz członków ASEAN również: USA, Australia, Chiny, Rosja, Japonia, Indie, Korea Południowa, Kanada, Australia, Nowa Zelandia, Mongolia, Papua Nowa Gwinea, Bangladesz, Sri Lanka, Timor Wschodni, Pakistan, KRL-D i UE.

Chiny w przeszłości nie miały zaufania do multilateralnego dialogu w sprawach bezpieczeństwa i preferowały rozmowy dwustronne. $Z$ czasem jednak stosunek ten zaczął się zmieniać, podobnie jak chińska definicja bezpieczeństwa. W lipcu 1998 r. Chiny opublikowały „Nową koncepcję bezpieczeństwa narodowego", gdzie oprócz tradycyjnych zagrożeń wymienione zostały nietradycyjne: piractwo, narkohandel, zagrożenie środowiska naturalnego i inne. Takie podejście znalazło pozytywną odpowiedź ASEAN i od tej pory dialog w zakresie bezpieczeństwa regionalnego dotyczy również nietradycyjnych zagrożeń. W lipcu 2000 r., w czasie wizyty w Indonezji, ówczesny wiceprezydent Chin Hu Jintao stwierdził: „Nowa koncepcja bezpieczeństwa, która obejmuje zasady równości, dialogu, zaufania i współpracy i nowy system bezpieczeństwa, powinna wypracować i wzmocnić przywiązanie do wzajemnego szacunku, współpracy wzajemnej poprzez konsultacje, pokojowe rozwiązywanie sporów niż poprzez wymuszanie, konfrontowanie i narzucanie własnej woli innym. Tylko w ten sposób państwa mogą współistnieć w przyjaźni i bezpiecznie się rozwijać” ${ }^{44}$. $\mathrm{Z}$ tego punktu widzenia bezpieczeństwo należy rozpatrywać niekoniecznie z militarnego punktu widzenia, ale politycznej stabilności, sukcesów gospodarczych i harmonii społecznej ${ }^{45}$. Jest to zbieżne z retoryką ASEAN way, podkreślającą solidarność krajów regionu, stabilność, współpracę, zaufanie i ich różnorodność.

Realizując wizję ASEAN 2020, w 2003 r. utworzono Wspólnotę Polityczną i Bezpieczeństwa (ASEAN Political-Security Community - APSC), która, wraz ze

${ }^{43}$ Liu Xuecheng, Strengthening ASEAN-China Cooperation in the ASEAN Regional Forum, [w:] ASEAN-China Relations..., s. 40.

${ }^{4}$ C.A. Thayer, China's New Security Concept and Southeast Asia, [w:] Asia Pacific Security, ed. D.W. Lowell, Canberra, Asia Pacific Press 2003, s. 91.

${ }^{45}$ Chulacheeb Chinawanno, The Dragon, the Bull and the Ricestalks: The Roles of China and India in Southeast Asia, [w:] ASEAN-China Relations..., s. 154. 
Wspólnotą Gospodarczą (ASEAN Economic Community) oraz Społeczno-Kulturową (ASEAN Socio-Cultural Community), stanowi trzy filary Wspólnoty ASEAN. Obecnie razem z ARF (ASEAN Regional Forum) APSC stanowi platformę współpracy w sektorze bezpieczeństwa. Z oficjalnych dokumentów APSC wynika, że najważniejsze cele polityczne to: rozwijanie i wzajemne zrozumienie systemów politycznych państw ASEAN, ich kultury i historii, swobodny przepływ informacji między państwami członkowskimi, wspieranie procesów ulepszania prawa, systemów sądownictwa i infrastruktury prawnej, promowanie dobrych rządów, ochrona praw człowieka, rozwój ośrodków badawczych i monitorowanie procesów politycznych, zapobieganie korupcji, promowanie zasad demokracji, dbałość o pokój i stabilizację w regionie. W planie działań APSC podkreślono znaczenie zasad zawartych w karcie ASEAN, Porozumieniu o przyjaźni i współpracy (Treaty of Amity and Cooperation - TAC), Porozumieniu o strefie wolnej od broni atomowej (SEANWFZ), jako kluczowych dokumentów dla bezpieczeństwa w regionie, oraz w Deklaracji o zachowaniu stron na Morzu Południowochińskim. Wymieniona została również współpraca morska. W dalszej części zwrócono uwagę na budowę środków wzajemnego zaufania, większą transparentność systemów obronnych i bezpieczeństwa państw oraz wzmocnienie roli ARF w umacnianiu bezpieczeństwa regionalnego. W kontekście umacniania bezpieczeństwa $\mathrm{w}$ regionie zostały również wymienione: zapobieganie konfliktom, tworzenie mechanizmów aktywnego poszukiwania pokoju, promowanie regionalnej współpracy, bezpieczeństwo społeczne oraz zwalczanie nietradycyjnych zagrożeń bezpieczeństwa (zapobieganie im) ${ }^{46}$.

Od 2004 r. chińskie Ministerstwo Spraw Wewnętrznych zorganizowało ponad 60 szkoleń i kursów na temat prawa antynarkotykowego, technik kryminalistycznych, cyberterroryzmu i innych tematów związanych z nietradycyjnymi zagrożeniami bezpieczeństwa; na szkolenia zaproszono 1500 oficerów z państw ASEAN. Tylko w okresie 2006-2011 MSW ChRL zorganizowało pięć takich szkoleń, na których było 92 oficerów z państw ASEAN ${ }^{47}$.

Z kolei chińska Akademia Nauk Wojskowych dwukrotnie - w 2008 i 2009 r. - organizowała konferencje dotyczące modernizacji militarnej i regionalnego zaufania wzajemnego oraz bezpieczeństwa we wschodniej Azji w kontekście współpracy bezpieczeństwa Chiny-ASEAN. W 2010 r. obie strony zorganizowały rozmowy polityków i ekspertów na temat bezpieczeństwa. W 2011 r. odbyło się pierwsze spotkanie ministrów obrony Chin i ASEAN ${ }^{48}$.

Najczęściej za najważniejszy sukces dialogu Chin w ramach ARF wymieniana jest Deklaracja na temat postępowania stron na Morzu Południowochińskim

46 ASEAN Political-Security Community Blueprint pdf, http://www.asean.org/archive/5187-18. pdf [dostęp 14.08.2012].

47 http://news.xinhuanet.com/english2010/china/2011-11/15/c_131248640_3.htm [dostęp 14.08.2012].

48 Ibidem. 
(Declaration on the Conduct of Parties in the South China Sea), podpisana w listopadzie 2002 r. Problemem jest jednak brak od tego czasu postępów w zakończeniu konfliktu.

Spór dotyczy archipelagów Paracele (po wietnamsku Hoang Sa), ale przede wszystkim Spratly (po wietnamsku Truong Sa, razem ok. 36 wysp), do których rości pretensje aż sześć państw: Chiny, Tajwan i Wietnam - do całych, Filipiny, Malezja, Brunei - do niektórych z nich. Wszystkie zainteresowane państwa, oprócz Brunei, myślą o umocnieniu tam swojej obecności militarnej, administracyjnej, regularnym transporcie itp. Wyspy jako takie nie przedstawiają większej wartości, ale istnieje podejrzenie, że są zasobne w ropę, gaz i inne bogactwa naturalne. Znaczenie ma również położenie strategiczne - połączenie Pacyfiku i Oceanu Indyjskiego. Ponad połowa handlu morskiego odbywa się z wykorzystaniem akwenu Morza Południowochińskiego, w tym ponad 80\% dostaw ropy dla Japonii, Południowej Korei, Chin oraz na Tajwan. Spośród wysepek największą ich liczbą administruje Wietnam - 22, Chiny - 14, Filipiny - 11, Malezja - 10, Tajwan - 1 (największa Itu Aba), Brunei - żadnąa .

Przyjęte w deklaracji rozwiązania nie są nowe, wszystkie były propozycjami wcześniejszych mechanizmów multi- i bilateralnych, ale są tu wpisane trzy specyficzne rozwiązania. Po pierwsze: powstrzymywanie się od akcji w kierunku niezamieszkałych aktualnie wysp, raf, skał, co oznacza, że nie może mieć miejsca żadna nowa okupacja. W tym punkcie deklaracji jest także mowa o budowie środków zaufania, notyfikowania w sprawie ćwiczeń czy manewrów morskich. Po drugie, mowa jest o kontynuowaniu regularnych konsultacji, o „obserwowaniu” i monitorowaniu wypełniania umowy. Nie jest to proste, ponieważ zgodnie z międzynarodowym prawem morza prawo stron do połowu ryb zazębia się $\mathrm{z}$ terenem spornym. Po trzecie, strony zgodziły się opracować kodeks postępowania.

Deklaracja nie jest układem, a raczej pokazuje, jak należy rozwiązać spór. Jak twierdzi Władimir Portiakow, udało się jedynie ,zakonserwować” spór ${ }^{50}$. We wrześniu 2004 r. Filipiny i Chiny zgodziły się podjąć wspólne badania sejsmiczne na spornych wodach i zidentyfikować występowanie gazu i ropy. Do porozumienia (Joint Marine Seismic Undertaking - JMSU) w 2005 r. przystąpił Wietnam. W marcu 2005 r. Wietnamska Korporacja Naftowa (Vietnam Petroleum Corporation - PetroVietnam), filipińska kompania Philippines National Oil Company (PNOC) oraz chińska China National Ofshore Oil Corporation (CNOOC) sfinalizowały w Manili trójstronną umowę o wspólnej eksploatacji ropy i gazu na Morzu Południowochińskim. Minister spraw zagranicznych Filipin Alberto Romulo oraz Wietnamu Nguyen Dy Nien wyrazili nadzieję, że jest to krok w do-

49 A.S.P. Baviera, The South China Sea Disputes after the 2002 Declaration: Beyond Confidences-Building, [w:] ASEAN-China Relations..., s. 345.

50 W. Portiakow, O niekotorych osobiennostiach wnieszniej politiki Kitaja w 2009-2011, „Problemy Dalniego Wostoka" 2012, nr 2, s. 34. 
brym kierunku. Po pracach rozpoznawczych te trzy państwa planowały prowadzić wspólną eksploatację złóż ropy i gazu przez firmy państwowe ${ }^{51}$.

W końcu kwietnia 2006 r. chińskie statki patrolowały Zatokę Tonkińską razem ze statkami wietnamskimi. Wspólne patrole, zdaniem chińskiego ministra spraw zagranicznych, to umocnienie bezpieczeństwa. Patrząc jednak na zachodzące procesy, można odnieść wrażenie, że rozwiązanie problemu przenosi się na grunt poza ASEAN, a niektóre państwa zyskują lepszą pozycję negocjacyjną z Chinamis ${ }^{52}$.

W latach 2009-2010 wyraźnie zaostrzył się problem wokół spornych archipelagów między Chinami a niektórymi z uczestniczących w sporze państw: Filipinami, Wietnamem, częściowo Malezją. Z powodu kończenia się terminu składania zażaleń w sprawie szelfu kontynentalnego wokół wysp, zgodnie z prawem morza z 1982 r., w maju 2009 r. Wietnam i Filipiny zaktywizowały swoje działania odnośnie do przypieczętowania de facto swojej suwerenności nad wyspami. W dniu 2 lutego 2009 r. parlament Filipin przyjął ustawę „O określeniu podstawowej linii granicznej filipińskiego archipelagu” (po filipińsku archipelag Kalaiaan). W dniu 10 marca ustawa została podpisana przez prezydenta Filipin, a 6 maja Wietnam i Malezja wniosły do ONZ wspólny projekt rozgraniczenia szelfu na Morzu Południowochińskim poza granice 200-milowej wyłącznej strefy ekonomicznej ${ }^{53}$. Stały przedstawiciel Chin w ONZ, w nocie skierowanej do obradujących, zaproponował, by nie rozpatrywać projektu Wietnamu i Malezji. Jednocześnie do komisji ONZ została przekazana chińska mapa Morza Południowochińskiego, na której zaznaczono granice ChRL obejmujące $80 \%$ spornych terytoriów. W dniu 8 maja Wietnam ponownie przekazał swój projekt, tym razem indywidualnie, a między Pekinem i Hanoi nastąpiła wymiana not protestacyjnych $^{54}$. Oliwy do ognia dolały dwie informacje: zapowiedź powrotu USA do Azji Wschodniej, którą Hillary Clinton złożyła 22 lipca 2009 r. na spotkaniu na wyspie Phuket w Tajlandii w czasie szczytu ARF, a oprócz tego propozycja włączenia problemu archipelagów do listy ,życiowych interesów Chin" ${ }^{55}$. Chociaż informacja ta nie została potwierdzona, to jednak pojawiły się wątpliwości, czy Pekin nadal chce prowadzić dobrosąsiedzką politykę.

W wypowiedziach chińskich ekspertów i politologów pojawiły się ostrzeżenia, że w końcu 2010 r. konfrontacyjna polityka wokół archipelagów, zwrot w stronę hard power w polityce zagranicznej i wzrost nastrojów nacjonalistycznych

51 M.A. Glosny, Stabilizing the Back Yard: Recent Development In China's Policy Toward Southeast Asia, [w:] China and the Developing World, eds. J. Eisenman, E. Hegingotham, D. Mitchell, KW Publishers Pvt Ltd. 2010, s. 165.

52 J. Dosch, op. cit., s. 223.

53 http://www.un.org/Depts/los/clcs_new/submissions_files/submission_mysvnm_33_2009. htm [dostęp 5.08.2012].

54 W. Portiakow, op. cit., s. 34.

55 Ibidem, s. 35. 
mogą zburzyć budowany konsekwentnie wizerunek państwa przyjaznego i pokojowego, traktującego kraje ASEAN nie jako poddanych, ale partnerów. Ostrzegano, że taka postawa negatywnie wpłynie na realizację interesów Chin i koncepcję pokojowego wzrastania.

To wszystko spowodowało, że pod koniec 2010 r. Pekin zmienił kurs, ponownie pokazując swoje pokojowe oblicze. Niemniej jednak do połowy następnego roku Chiny prezentowały siłę w sprawie Wysp Paracelskich, np. 26 maja trzy chińskie statki zablokowały wietnamski statek należący do państwowej kompanii naftowej Binh Minh2, a 2 czerwca agencje informacyjne doniosły o strzałach ostrzegawczych skierowanych w stronę wietnamskich łodzi rybackich, które znajdowały się pięć mil morskich od wyspy Da Dong w archipelagu Spratly ${ }^{56}$. Żadna ze stron nie chciała przedłużenia konfliktu i w czasie wizyty lidera Komunistycznej Partii Wietnamu Nguyen Phu Tronga w Chinach osiągnięto kompromis i podpisano Porozumienie o podstawowych zasadach uregulowania problemów morskich między ChRL i SRW ${ }^{57}$. W porozumieniu obie strony zobowiązały się do niepodejmowania żadnych kroków, które mogłyby zaostrzyć sytuację.

Jeśli chodzi o Filipiny, to w czasie wizyty w Chinach prezydenta Benigno Akino mówiono o konflikcie, ale strony nie zbliżyły swoich stanowisk. Dodatkowo udział Filipin w manewrach wojskowych ze Stanami Zjednoczonymi spowodował rozdrażnienie Pekinu, a nawet zapowiedź ukarania Filipin za chęć „przyłączenia się do USA w celu powstrzymywania Chin"58. Stany Zjednoczone do wspólnych ćwiczeń Cobra Gold próbują włączyć wszystkie państwa, które mają nierozwiązane spory graniczne z Chinami, ale również Tajlandię, która cieszy się dobrymi kontaktami z sąsiadem.

Na początku 2012 r. napięcie wokół wysp zelżało, a 14 stycznia w Pekinie odbyła się narada w sprawie wypełnienia postanowień deklaracji z 2002 r. Ponieważ sytuacja międzynarodowa pokazuje, że nie ma możliwości wprowadzenia w życie maksymalnych planów Pekinu, brane są pod uwagę warianty pośrednie, np. zamiast odzyskania suwerenności nad spornymi archipelagami Chiny chcą mieć kontrolę nad samym morzem. W dniu 29 lutego 2012 r. oficjalny przedstawiciel MSZ ChRL Hun Lei oświadczył, że żaden kraj, w tym Chiny, nie żądają ustanowienia swojej suwerenności nad całym Morzem Południowochińskim. Wielu ekspertów twierdzi, że dla dobra chińskiego odrodzenia i modernizacji oraz wzrostu należy nie stawiać na ostrzu noża suwerenności nad archipelagami politykę - „odrodzenie Chin wymaga strategicznej mądrości i strategicznej cierpliwości" ${ }^{59}$. Mimo to w lipcu 2012 r. miał miejsce kolejny incydent - Chińczycy podjęli decyzję o utworzeniu na wyspie Phu Lam bazy wojskowej Sansha City i prze-

\footnotetext{
$56 \mathrm{http}: / / w w w . t h a n h n i e n n e w s . c o m / 2010 /$ pages/20110602115938.aspx [dostęp 15.09.2011].

57 W. Portiakow, op. cit., s. 37.

58 Ibidem, s. 38.

59 Ibidem.
} 
prowadzeniu tam wyborów ${ }^{60}$. Członkowie ASEAN nie są zgodni co do dalszych wspólnych działań w tej sytuacji. W listopadzie 2012 r. poparli pozycję Chin, że nie będą dążyć do umiędzynarodowienia konfliktu wokół spornych wysp, co oznacza zwycięstwo opcji prochińskiej.

Za sukces współpracy Chin z państwami regionu w ramach ARF można uznać podpisanie w 2002 r. Memorandum na temat nietradycyjnych zagrożeń bezpieczeństwa (Memorandum of Understanding in the Field of Non-Traditional Security Issues). Susan L. Craig wymienia wiele zagrożeń uznanych przez stronę chińską za ważne ${ }^{61}$. W książce na temat nietradycyjnych zagrożeń bezpieczeństwa w 2003 r., opublikowanej przez Chiński Instytut Współczesnych Stosunków Międzynarodowych, było rozpatrywanych w tym kontekście siedemnaście zagrożeń. Wpisane do Chińskiej Białej Księgi Obrony Narodowej w roku 2004, powtórzone w roku $2010^{62}$, zostały oficjalnie uznane za część doktryny bezpieczeństwa. Współpraca Chin z ARF dotyczyła odtąd m.in.: walki z terroryzmem, nielegalną emigracją, handlu ludźmi, przemytu narkotyków, przeciwdziałaniu separatyzmom. Takie spojrzenie na kwestie bezpieczeństwa niekiedy jest kontestowane przez kręgi wojskowych, bo, jak np. twierdzą malezyjscy wojskowi, „nietradycyjne zagrożenia bezpieczeństwa to nie nasza sprawa" ${ }^{63}$.

W 2003 r. Chiny przystąpiły do TAC oraz podjęły rozmowy na temat Protokołu Strefy Wolnej od Broni Atomowej w Azji Południowo-Wschodniej (Protocol to the Treaty on Southeast Asia Nuclear Weapon Free Zone) ${ }^{64}$. Podpisanie wspólnej deklaracji na temat strategicznego partnerstwa (Joint Declaration on the Strategic Partnership for Peace and Prosperity) w Bali ${ }^{65}$ było kolejnym krokiem w kierunku rozwinięcia współpracy politycznej i w dziedzinie bezpieczeństwa.

Najważniejszym chińskim projektem było zwołanie konferencji ARF na tematy polityczne i bezpieczeństwa (ARF Security Policy Conference ASPC) w $2004 \mathrm{r}$. do Pekinu. W roku 2005 kolejną konferencję zwołano w Vientiane, a w 2009 r. ASPC odbyła się w Phuket w Tajlandii i w czasie jej obrad dużo uwagi, oprócz światowego kryzysu gospodarczego, poświęcono nietradycyjnym zagrożeniom bezpieczeństwa; w 2010 r. spotkano się w Da Nang (Wietnam). W 2009 r. w Pekinie zebrała się pierwsza międzysesyjna konferencja na temat nieproliferacji i rozbrojenia $^{66}$. W dniu 25 maja 2012 r. ASPC debatowała w Kambodży i tutaj z kolei

${ }^{60} \mathrm{http}: / /$ www.thanhniennews.com/index/pages/20120810-us-china-in-east-sea-scrap.aspx [dostęp 3.01.2013].

${ }^{61}$ S.L. Craig, Chinese Perceptions of Traditional and Nontraditional Security Threats, March 2007, http://www.strategicstudiesinstitute.army.mil/pdffiles/pub765.pdf [dostęp 30.05.2011].

${ }_{62}$ Tekst zob. http://news.xinhuanet.com/english2010/china/2011-03/31/c_13806851.htm [dostęp 17.08.2012].

63 J. Dosch, op. cit., s. 217.

${ }^{64} \mathrm{http} / / / w w w . n t i . o r g / d b / c h i n a /$ bangkok.htm [dostęp 20.10.2011].

${ }_{65} \mathrm{http} / / /$ www.aseansec.org/16805.htm [dostęp 20.10.2011].

66 Sprawozdanie z konferencji zob. ASEAN Regional Forum, Documents Series, 2006-2009, s. 314, http://www.aseansec.org/publications/ARF06-09.pdf [dostęp 20.10.2011]. 
członkowie ARF zwrócili uwagę na ostatnie wydarzenia, związane ze spornymi archipelagami Spratly i Paracele, w kontekście bezpieczeństwa morskiego.

Dla Chin bezpieczeństwo morskie ma duże znaczenie, zwłaszcza w Zatoce Malakka. Chińscy uczeni, opierając się na retoryce pokojowego wzrastania, zwracają uwagę na sześć zasad i dziewięć form współpracy między Chinami i ASEAN w zakresie regionalnego bezpieczeństwa morskiego. Do sześciu zasad zaliczyli: wzajemny szacunek, wzajemne uznanie interesów, wzajemne zaufanie i korzyści, równoprawne negocjacje i koordynację, efektywność i trwały rozwój. Dziewięć form współpracy to: dialog na temat bezpieczeństwa morskiego, konsultacje na temat bezpieczeństwa żeglugi, operacje antyterrorystyczne, ratownictwa morskiego, ochrona środowiska morskiego, wspólne prawo przeciw przestępczości transnarodowej, wspólne manewry morskie oraz regionalne operacje pokojowe i humanitarne $e^{67}$.

Globalizacja sprawiła, że owe akweny wodne są ważne z kilku powodów. Po pierwsze, są to trasy strategiczne dla handlu, np. przez Cieśninę Malakka, „jedwabny morski szlak”, jest transportowane $80 \%$ chińskiego importu ropy z Bliskiego Wschodu. Po drugie, morza te są bardzo bogate w ryby czy ropę, gaz i inne surowce naturalne. Pokojowe wykorzystanie morza ma odgrywać aktywną rolę promującą w rozwoju gospodarczym regionu.

Chiny są zainteresowane, by ARF pozytywnie włączył się do procesu zmniejszenia napięcia na Półwyspie Koreańskim. Uczestnicy rozmów sześciostronnych zostali zaproszeni na szczyt ARF w 2010 r. (Hanoi) i w 2011 r. (na Bali). Dyskusja na forum ARF na temat denuklearyzacji Półwyspu jest formą multilateralnego podejścia do problemu, a zarazem daje możliwość skorzystania z wypracowanej już przez ARF dyplomacji prewencyjnej.

Chiny nie zaniedbują relacji dwustronnych z państwami regionu, ustanawiając z niektórymi z nich relacje strategiczne. W listopadzie $2007 \mathrm{r}$. podpisały porozumienie o partnerstwie strategicznym z Indonezją, którą reprezentował minister obrony Cao Gangchuan. Było to pierwsze tego typu porozumienie podpisane między Chinami i członkiem ASEAN. W czasie państwowej wizyty prezydenta Myanmaru Thein Sein w Chinach w dniach 26-28 maja 2011 r. obie strony określiły wzajemne relacje jako strategiczne partnerstwo.

Wspólny komunikat premiera Chin Wen Jiabao i premiera Królestwa Tajlandii Yingluck Shinawatra z 19 kwietnia 2012 r. zakłada również budowę strategicznych relacji między obu państwami.

Polepszenie stosunków ASEAN-Chiny dotyczy również relacji wojskowych i handlu bronią. Do 1989 r., poza Tajlandią, jedynie Kambodża kupowała od Chin broń. W 1991 r. do tego klubu dołączyły Laos i Myanmar, gdy na dogodnych

${ }^{67}$ Saw Swee-Hock, Sheng Lijun, Chin Kin Wah, op. cit., s. 10; Wang Zhongchun, Li Yaqiang, China-ASEAN Maritime Security Cooperation Situation and Proposals, [w:] ibidem, s. 194-198. 
warunkach Laos kupił dwa samoloty Y-12, a Myanamar zamówił chiński sprzęt wojskowy, w tym okręty wojenne oraz 12 samolotów F-6 ${ }^{68}$.

Polityka Chin wobec Myanmaru na przełomie lat 80 . i 90 . XX w. rozpatrywana była przez ASEAN jako destabilizująca region. W połowie lat 90 . Chiny stały się największym partnerem handlowym Myanmaru, a w październiku 1989 r. strony uzgodniły sprzedaż wysokich technologii wojskowych na sumę 1 mld USD ${ }^{69}$. Na wyspie Coco (Wyspy Kokosowe) chińscy specjaliści zbudowali lotnisko wojskowe. W połowie $2001 \mathrm{r}$. Chiny sprzedały Myanmarowi broń na sumę 2 mld USD. Do połowy $2004 \mathrm{r}$. strony podpisały ponad 50 różnego typu porozumień.

Rozwija się współpraca wojskowa z Tajlandią. Zgodnie z nowym porozumieniem Instytut Technologii Obronnej będzie wspólnie z chińskimi specjalistami pracował nad wieloprowadnicowymi wyrzutniami rakietowymi (multiple rocket launchers), zwanymi „DTI-1G”. Do tej pory obie strony współpracowały przy produkcji rakiet typu DTI-1, których zasięg wynosił od 60 do $180 \mathrm{~km}$, ale brakowało im precyzyjności. Nowy system ma być, zdaniem ministra obrony Tajlandii Sukumopola Suwanatata, bardziej precyzyjny, a ponadto ma posiadać większy zasięg.

W czasie wizyty obie strony uzgodniły również przeprowadzenie po raz pierwszy wspólnych ćwiczeń sił powietrznych. Innym przykładem zacieśniania się współpracy wojskowej między dwoma krajami jest udział 130 oficerów Królewskiej Marynarki Wojennej Tajlandii we wspólnych manewrach w Guangdong na południu Chin w dniach 9-29 maja 2012 r. $^{70}$

\section{Wykorzystanie soft power Chin w stosunku do państw regionu Azji Południowo-Wschodniej}

Najbardziej konstruktywną metodą, przynoszącą najlepsze efekty w kontaktach z ASEAN, jest pokazanie atrakcyjności modelu rozwojowego Chin, który w odróżnieniu od państw Zachodu, nie jest kombinacją wolnego rynku i demokracji liberalnej, ale półrynkowego systemu gospodarczego i nieliberalnego systemu politycznego, opartego na rządach partii komunistycznej. Ten „konsensus pekiński”, w odróżnieniu od „waszyngtońskiego”, może być bardziej atrakcyjny dla wielu państw regionu. Chińskie soft power w Azji Południowo-Wschodniej, jak sądzi Ignatius Wibowo, może uwzględniać chińską kulturę, zasady współpracy i uczestnictwa w multilateralizmie ASEAN ${ }^{71}$. Przytaczanym już w artykule

68 S. Rajasinman, China-ASEAN Relations - Emerging Asian Security Architecture, [w:] China and Its Neighbours, ed. S. Kondapalli, Pentagon, Press New Delhi 2010, s. 117.

${ }^{69}$ I. Kanajew, op. cit., s. 112.

$70 \mathrm{http} / /$ www.bangkokpost.com/news/local/290809/top-brass-china-visit-secures-joint-missile-deal [dostęp 3.05.2012].

71 I. Wibowo, China's Soft Power and Neoliberal Agenda in Southeast Asia, [w:] Soft Power. China's Emerging Strategy in International Politics, eds. Mingjiamg Li, Lexington Books 2011, s. 208. 
przykładem pozytywnej odpowiedzi na problemy ASEAN był kryzys 1997 r. Pomoc ze strony Chin przyszła wówczas, gdy Międzynarodowy Fundusz Walutowy i Bank Światowy odpowiedziały pogrążającym się w kryzysie państwom, że muszą wprowadzić trzy reformy: deregulację, pełną prywatyzację i liberalizację gospodarczą oraz demokratyzację polityki. Okazało się wówczas, że Chiny bez tego typu reform były w stanie poradzić sobie w kryzysie oraz pomóc w inny od MFW i BŚ sposób, bardziej odpowiadający potrzebom państw ASEAN. Nawet na Zachodzie podziwiany jest chiński styl dyplomacji. Jedynie Chiny mają możliwość i umiejętność mediowania z izolowanymi państwami. Przykładem jest chińska rola $\mathrm{w}$ rozmowach sześciostronnych.

Opisywanym wcześniej wspólnym działaniom na polu gospodarczym i bezpieczeństwa $\mathrm{w}$ regionie towarzyszyły często powtarzane deklaracje dotyczące wzajemnego zaufania oraz ścisłej, korzystnej wzajemnie współpracy i integracji. Chińskie soft power polega na przekazaniu informacji, że są państwem odpowiedzialnym i niosącym pomoc. W sposób szczególny były traktowane państwa basenu rzeki Mekong: Myanmar, Kambodża, Laos i Wietnam, a przecież zwłaszcza Kambodża i Wietnam miały przykre doświadczenia historyczne z Chinami. Wystarczy wymienić poparcie Chin dla reżimu Czerwonych Khmerów czy wojnę graniczną z Wietnamem w 1979 r. Również kontakty z innymi państwami: Tajlandią, Malezją, Filipinami czy Indonezją zdecydowanie się polepszyły, niezależnie od ich wcześniejszych „grzechów” współpracy ze Stanami Zjednoczonymi w okresie konfliktów indochińskich czy traktowania mniejszości chińskiej.

W 2010 r. członek Rady Państwowej ChRL Dai Bingguo złożył oświadczenie, opublikowane na stronach Ministerstwa Spraw Zagranicznych, w którym zapewniał, że Chiny nie mają żadnych tajnych ambicji polegających na osiągnięciu hegemonii, wręcz przeciwnie - są przywiązane do drogi pokojowego rozwoju. Dodawał, że nie należy bać się Chin, ale pomagać im i popierać ich rozwój.

W dniu 6 września 2011 r. została opublikowana Biała księga dotycząca pokojowego rozwoju Chin, w której zostały powtórzone niektóre tezy z oświadczenia członka Rady Państwowej. Chińczycy powołują się w niej na swoje dziedzictwo kulturowe i wartości humanistyczne. Jest tu sformułowana prośba o zaufanie i wiarę w szczerość intencji Chin ze strony społeczności międzynarodowej, o wsparcie ich pokojowego rozwoju, którego celem jest zlikwidowanie biedy i życie $\mathrm{w}$ dostatku ${ }^{72}$. W Białej księdze zostały wymienione następujące cele polityki chińskiej: budowa harmonijnego świata, pokojowa polityka zagraniczna, promowanie nowego myślenia na temat bezpieczeństwa, wzajemnego zaufania, wzajemnej korzyści, równości i koordynacji, aktywna międzynarodowa odpowiedzialność oraz rozwijanie regionalnej współpracy i dobrosąsiedzkich relacji³ ${ }^{73}$.

${ }^{72}$ http://www.china-embassy.org/eng/zt/zhongguodehepingfazhan/t856269.htm [dostęp 15.08.2012].

73 Pełny tekst Białej księgi zob. http://news.xinhuanet.com/english2010/china/2011-09/06/ c_131102329_4.htm [dostęp 15.08.2012]. 
Ten aspekt retoryki został wprowadzony do praktyki dyplomatycznej Chin - przyjęto kurs na utwierdzenie w świecie wiarygodnego, życzliwego obrazu Chin, państwa odpowiedzialnego za sytuację międzynarodową. Jego realizacja ma nastąpić poprzez zwiększanie atrakcyjności kultury Chin, oddziaływania chińskiej kultury na świecie. W 2011 r. rząd chiński wydał Białą księgę o rezultatach współpracy Chin z ASEAN za lata 1991-2011. Celem tego dokumentu było pokazanie wysokiej dynamiki rozwoju relacji wzajemnych w różnych sferach, by państwa ASEAN uwierzyły, że Chiny są ich dobrym przyjacielem, sąsiadem i partnerem.

Chiny zaczęły wykorzystywać szeroką gamę środków związanych z dyplomacją kulturalną. W państwach ASEAN pojawiły się programy nauki języka chińskiego, a także wolontariusze chińscy uczący języka. Wspomniany program szkoleń dla urzędników resortu bezpieczeństwa państw regionu również zawierał naukę chińskiego. „Chińska kultura, kuchnia, kaligrafia, kino, sztuka, akupunktura, medycyna tradycyjna, moda weszły do kultury regionu" 74 .

Najbardziej rozpowszechnioną formą nauki języka chińskiego są obecnie tzw. Instytuty Konfucjusza. Mają one dwa podstawowe cele: edukacyjny oraz różne formy dyplomacji kulturalnej. Pierwszy Instytut powstał w 2004 r. w Korei Południowej, został powołany przez Han Ban, czyli Biuro Międzynarodowej Rady Języka Chińskiego. Od tej pory utworzono 353 Instytuty Konfucjusza oraz 473 klasy Konfucjusza w 104 krajach. Ponieważ jedynie w 33 uniwersytetach chińskich korzysta się z programu dla nauczycieli języka chińskiego jako obcego, kształcącego 1500 nauczycieli każdego roku, w marcu 2004 r. Ministerstwo Edukacji uruchomiło program dla wolontariuszy z zagranicy uczących chińskiego. Zakończył się on, niestety, fiaskiem i nadal liczba nauczycieli chińskiego jest niewystarczająca ${ }^{75}$. Obecnie w państwach ASEAN istnieje 41 Instytutów Konfucjusza, ale są rozmieszczone nierównomiernie: najwięcej jest w Tajlandii (23), w Indonezji siedem, na Filipinach trzy, w Malezji, Singapurze i Myanamarze po dwa, w Laosie i Kambodży po jednym.

W maju 2012 r. po raz pierwszy spotkali się ministrowie kultury w ramach formuły $10+1$, a we wrześniu ministrowie nauki. W Chinach otwarto dziesięć centrów szkolenia zawodowego dla państw ASEAN, w tym rolnicze, alternatywnych źródeł energii, medycyny tradycyjnej, kultury i sztuki w sześciu prowincjach chińskich ${ }^{76}$. Rośnie liczba studentów państw ASEAN studiujących w Chinach.

${ }^{74}$ Eric Teo, Chu Cheow, ASEAN+3: The Role of ASEAN and China, [w:] ASEAN-China Relations, Realities and Prospects, ed. Saw Swe-Hock, Singapore ISEAS, 2005, s. 63.

75 Zhe Ren, The Confucius Institutes and China's Soft Power, „IDE Discussion Paper” 2012, no. 330, s. 9, http://www.ide.go.jp/English/Publish/Download/Dp/330.html [dostęp 20.08.2012].

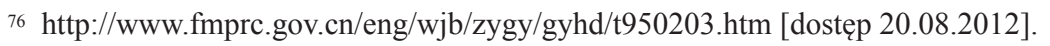


Tabela 5.5.

Liczba studentów państw ASEAN studiujących w Chinach

\begin{tabular}{|l|c|c|c|c|}
\hline \multicolumn{1}{|c|}{ Państwo } & $\begin{array}{c}\text { Liczba studentów } \\
\text { w 2002 }\end{array}$ & $\begin{array}{c}\text { Liczba studentów } \\
\text { w 2003 }\end{array}$ & $\begin{array}{c}\text { Liczba studentów } \\
\text { w 2004 }\end{array}$ & $\begin{array}{c}\text { \% wzrostu } \\
\text { 2002-2004 }\end{array}$ \\
\hline Brunei & 4 & 4 & 6 & 50 \\
Kambodża & 151 & 139 & 163 & 19 \\
Indonezja & 2583 & 2563 & 3750 & 45 \\
Laos & 333 & 403 & 509 & 53 \\
Malezja & 840 & 841 & 1241 & 48 \\
Myanmar & 232 & 232 & 397 & 71 \\
Filipiny & 638 & 602 & 1375 & 115 \\
Singapur & 583 & 551 & 929 & 59 \\
Tajlandia & 1737 & 1554 & 2371 & 36 \\
Wietnam & 2226 & 3487 & 4382 & 88 \\
\hline
\end{tabular}

Źródło: PRC Ministry of Foreign Affairs, Zhongguo Waijiao (China Diplomacy), Beijing World Press, 2003-2005.

Na podstawie oficjalnych danych ASEAN można przytoczyć kolejne inicjatywy, które mają zwiększyć liczbę studentów wyjeżdżających do Chin. W sierpniu 2011 r. miał miejsce czwarty tydzień współpracy w dziedzinie edukacji Chiny-ASEAN w Guiyang w chińskiej prowincji Guizhou, gdzie była mowa o programie mobilności studentów. Strony zaplanowały zwiększenie do 100 tys. liczby studentów wyjeżdżających do Chin na studia oraz studentów chińskich do państw ASEAN do 2020 r. W czasie 13. szczytu ASEAN-Chiny, który odbywał się w październiku 2010 r. w Hanoi, Chiny zaprosiły 10 tys. młodych nauczycieli, studentów i wykładowców w ciągu kolejnych 10 lat, a na 14. szczycie na Bali, w listopadzie 2011 r., zaoferowały 10 szkoleń zawodowych dla członków ASEAN ${ }^{77}$.

\section{Podsumowanie}

Region Azji Południowo-Wschodniej jest szczególnie ważny i strategiczny dla Chin zarówno jeśli chodzi o tradycyjne bezpieczeństwo, jak i o interesy gospodarcze. Z chińskiej perspektywy USA i ZSRR użyły regionu przeciw Chinom w czasie zimnej wojny, obecne działania Pekinu mają utrwalić tradycyjne bliskie relacje i zapobiec destrukcyjnym działaniom państw trzecich w relacjach ChinyASEAN.

77 http://www.aseansec.org/5874.htm [dostęp 20.08.2012]. 
Kraje Azji Południowo-Wschodniej to bezpośredni sąsiedzi Chin, większość chińskiego handlu, włączając $w$ to ropę naftową, przechodzi przez morza Azji Południowo-Wschodniej Ponadto sam handel wspomaga rozwój ekonomiczny południowych prowincji: Yunnan i Guangxi. Poprawa relacji Chiny z regionem oznacza silniejszą pozycję w ich handlu i stosunkach z USA. Nieuprawnione byłoby stwierdzenie, że Chiny budując przyjazne otoczenie w regionie, chcą wyeliminować stąd USA, ale oczywiste jest, że chcą stworzyć swoją przyjazną strefę i przez wzgląd na własną modernizację dążą do umocnienia regionalnej integracji.

Obecnie stosunki ASEAN-Chiny są dobre jak nigdy przedtem. Duży wpływ miało na to zachowanie Chin w czasie kryzysu azjatyckiego 1997 r. i po nim oraz konsekwentne budowanie wizerunku państwa przyjaznego i odpowiedzialnego. Jak stwierdził premier Wen Jiabao, zarówno Chiny, jak i ASEAN muszą się nawzajem szanować, ufać sobie, dbać o wzajemne interesy w taki sposób, aby jedna strona nie rozwijała się kosztem drugiej ${ }^{78}$.

Nie wszyscy eksperci są skłonni uwierzyć w zapewnienia chińskich przywódców. Joshua Kurlantzick interpretuje te działania następująco: „Pekin rzeczywiście oferuje »czarującą ofensywę«, która polega na uroku lwa, nie myszy: może zagrażać innym narodom swoimi pazurami, jeśli nie pomogą Chinom osiągnąć celów, ale może zaoferować wielką marchewkę, jeśli będą to robić" 79 .

Wątpliwości budzą też intencje Pekinu. Zwłaszcza państwa indochińskie mają przykre doświadczenia i obawiają się chińskich wpływów i dominacji. O koniunkturalizmie świadczą działania zmierzające do izolacji Tajwanu. Wszystkie państwa musiały uznać jedne Chiny, a nie Tajwan, co jest warunkiem wstępnym współpracy.

Chiny wykorzystują całą gamę środków dyplomatycznych, aby wyeliminować te negatywne emocje i obawy o zagrożenie $\mathrm{z}$ ich strony, poczynając od silniejszego wspierania regionalnego multilateralizmu, po umacnianie interakcji z liderami ASEAN. Wielość form bezpośredniej współpracy międzypaństwowej i międzyresortowej sprawia, że obecnie więzy łączące oba podmioty wydają się nierozwiązywalne, zwłaszcza zaś współpraca gospodarcza w ramach CAFTA. Chiny przegoniły już znaczących graczy w regionie i pełnią rolę inicjatora wielu przedsięwzięć. Państwa ASEAN godzą się na tę sytuację i chcą zaangażować je poprzez multilateralne organizacje. Za ich pośrednictwem mogą się zaznajamiać z intencjami, możliwościami i mogą ,socjalizować” Chiny, aby stały się one bardziej odpowiedzialne.

\footnotetext{
78 S. Rajasimman, op. cit., s. 112.

79 J. Kurlantzick, op. cit., s. 6.
} 